\title{
Regulation of DNA synthesis and the cell cycle in human prostate cancer cells and lymphocytes by ovine uterine serpin Maria B Padua and Peter J Hansen*
}

\author{
Address: Department of Animal Sciences, University of Florida, Gainesville, FL 32611-0910, USA \\ Email: Maria B Padua -mpadua@ufl.edu; Peter J Hansen* - hansen@animal.ufl.edu \\ * Corresponding author
}

Published: 24 January 2008

BMC Cell Biology 2008, 9:5 doi: |0.1 |86/|47|-2|2|-9-5

This article is available from: http://www.biomedcentral.com/I47|-2/2I/9/5

(c) 2008 Padua and Hansen; licensee BioMed Central Ltd.

This is an Open Access article distributed under the terms of the Creative Commons Attribution License (http://creativecommons.org/licenses/by/2.0), which permits unrestricted use, distribution, and reproduction in any medium, provided the original work is properly cited.
Received: 17 August 2007

Accepted: 24 January 2008

\begin{abstract}
Background: Uterine serpins are members of the serine proteinase inhibitor superfamily. Like some other serpins, these proteins do not appear to be functional proteinase inhibitors. The most studied member of the group, ovine uterine serpin (OvUS), inhibits proliferation of several cell types including activated lymphocytes, bovine preimplantation embryos, and cell lines for lymphoma, canine primary osteosarcoma and human prostate cancer (PC-3) cells. The goal for the present study was to evaluate the mechanism by which OvUS inhibits cell proliferation. In particular, it was tested whether inhibition of DNA synthesis in PC-3 cells involves cytotoxic actions of OvUS or the induction of apoptosis. The effect of OvUS in the production of the autocrine and angiogenic cytokine interleukin (IL)- 8 by PC-3 cells was also determined. Finally, it was tested whether OvUS blocks specific steps in the cell cycle using both PC-3 cells and lymphocytes.
\end{abstract}

Results: Recombinant OvUS blocked proliferation of PC-3 cells at concentrations as low as $8 \mu \mathrm{g} /$ $\mathrm{ml}$ as determined by measurements of $\left[{ }^{3} \mathrm{H}\right]$ thymidine incorporation or ATP content per well. Treatment of PC-3 cells with OvUS did not cause cytotoxicity or apoptosis or alter interleukin-8 secretion into medium. Results from flow cytometry experiments showed that OvUS blocked the entry of PC-3 cells into $S$ phase and the exit from $G_{2} / M$ phase. In addition, OvUS blocked entry of lymphocytes into $S$ phase following activation of proliferation with phytohemagglutinin.

Conclusion: Results indicate that OvUS acts to block cell proliferation through disruption of the cell cycle dynamics rather than induction of cytotoxicity or apoptosis. The finding that OvUS can regulate cell proliferation makes this one of only a few serpins that function to inhibit cell growth.

\section{Background}

Serine proteinase inhibitors (serpins) inactivate their target proteinases through a suicide substrate-like inhibitory mechanism. The proteinase binds covalently to the reactive center loop (RCL) of the serpin and cleaves the scissile bond at the P1-P1' site. The RCL then moves to the opposite side to form the $\beta$-sheet $A$ and a distortion in the structure of the proteinase that results in its inactivation [1-3].
Not all serpins, however, exert proteinase inhibitory activity. Some examples are corticosteroid and thyroxine binding globulins, which function as hormone transport proteins [4], the chaperone heat shock protein 47 [5], mammary serine protease inhibitor (Maspin), which increases the sensitivity of cancer cells to undergo apoptosis [6], and pigment epithelium derived factor (PEDF), 
which has neurotrophic, neuroprotective, antiangiogenic, and proapoptotic actions [7].

Another class of serpins without apparent proteinase activity is the uterine serpins. These proteins, which are produced by the endometrial epithelium of the pregnant cow, sow, sheep, and goat [8-13], have been classified as either a separate clade of the serpin superfamily [14] or as a highly-diverge group of the $\alpha 1$-antitrypsin clade [1]. The best characterized protein of this unique group of serpins is ovine uterine serpin (OvUS). This basic glycoprotein is a weak inhibitor of aspartic proteinases (pepsin A and C) $[12,15]$, but it does not inhibit a broad range of serine proteinases $[9,16]$. Additionally, amino acids in the hinge region of inhibitory serpins are not conserved in uterine serpins and OvUS behaves different in the presence of guanidine $\mathrm{HCl}$ than for inhibitory serpins $[13,15]$.

The biological function of OvUS during pregnancy may be to inhibit immune cell proliferation during pregnancy and provide protection for the allogeneically-distinct conceptus [17]. Ovine US decreases proliferation of lymphocytes stimulated with concanavalin A, phytohemagglutinin (PHA), Candida albicans, and the mixed lymphocyte reaction [18-22]. In addition, OvUS decreases natural killer cell cytotoxic activity, abortion induced by poly(I)poly $(\mathrm{C})$ in mice [23] and the production of antibody in sheep immunized with ovalbumin [21]. The antiproliferative actions of OvUS are not limited to lymphocytes. Ovine US decreases development of the bovine embryos and proliferation of mouse lymphoma, canine primary osteogenic sarcoma and human prostate cancer cell lines $[24,25]$.

The mechanism by which OvUS inhibits proliferation of cells is unknown. The protein could block activation of cell proliferation, inhibit the cell cycle at other points or induce apoptosis or other forms of cell death. For the PC3 prostate cancer line, inhibition of cell proliferation by OvUS might involve reduction in interleukin-8 (IL-8) secretion because of the importance of autosecretion of this cytokine for cell androgen-independent proliferation [26]. The goal of the present study was to evaluate the mechanism by which OvUS inhibits cell proliferation. Using PC-3 cells as a model system, it was tested whether inhibition of DNA synthesis involves cytotoxic action of OvUS, induction of apoptosis or disruption of the IL-8 autocrine loop. It was also tested whether OvUS blocks specific steps in the cell cycle for PC-3 cells and lymphocytes.

\section{Results and Discussion Proliferation of PC-3 cells}

The antiproliferative effects of rOvUS on proliferation of PC-3 cells were evaluated by two different assays. In the first experiment, it was shown that rOvUS caused a concentration-dependent decrease in incorporation of $\left[{ }^{3} \mathrm{H}\right]$ thymidine into DNA $(\mathrm{P}<0.001)$ with the minimum effective concentration being $8 \mu \mathrm{g} / \mathrm{ml}$ (Figure 1 ). The antiproliferative actions of OvUS using $\left[{ }^{3} \mathrm{H}\right.$ ] thymidine uptake as the measure of proliferation has been demonstrated previously for PC-3 cells and other cell types [18$22,24,25]$. To confirm this effect of rOvUS reflected an inhibition in cell proliferation and not a disruption in $\left[{ }^{3} \mathrm{H}\right]$ thymidine uptake by the cells, antiproliferative effects were also evaluated by an assay in which the relative total number of cells per well was estimated by the ATP content per well. Treatment with rOvUS reduced ATP content per well at all concentrations tested (50,100 and $200 \mu \mathrm{g} / \mathrm{ml}$ ) (Figure 2). In contrast, the control serpin, ovalbumin, did not cause effect in the ATP content per well. The finding that rOvUS reduced ATP content per well confirms that the effects of OvUS to reduce $\left[{ }^{3} \mathrm{H}\right]$ thymidine incorporation reflect a reduction in cell proliferation rather than interference with $\left[{ }^{3} \mathrm{H}\right]$ thymidine transport into the cell.

\section{Lactate dehydrogenase release}

Possible cytotoxic effects of rOvUS on PC-3 cells were evaluated by measurements of lactate dehydrogenase release into culture medium (Figure 3 ). None of the concentrations of rOvUS or OVA tested caused an increase in the percent of lysed cells during culture. Thus, rOvUS does not inhibit proliferation through induction of cell death.

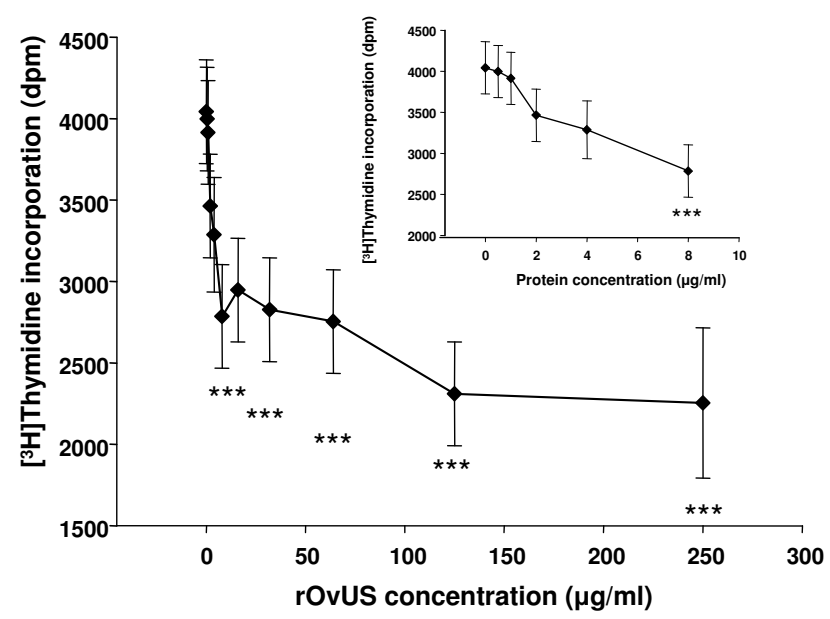

\section{Figure I}

Inhibition of $\left[{ }^{3} \mathrm{H}\right]$ thymidine incorporation of $\mathrm{PC}-3$ cells by recombinant ovine uterine serpin (rOvUS). The inset graph is provided to clarify the effects of rOvUS at lower concentrations $(\leq 8 \mu \mathrm{g} / \mathrm{ml})$. Data represent least-squares means $\pm \mathrm{SEM}$. Values that differ from untreated cells are indicated by asterisks (***P $<0.001)$. 


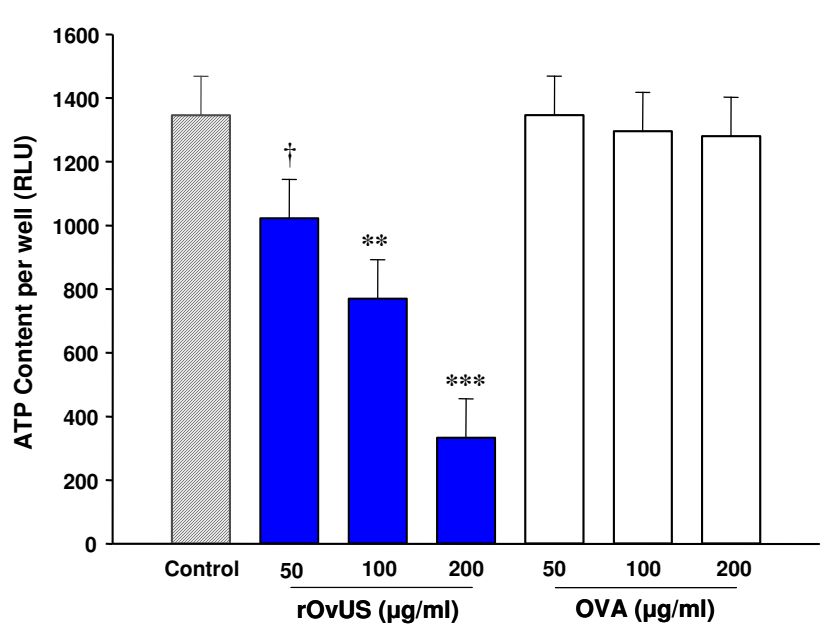

Figure 2

Inhibition of proliferation of PC-3 cells by recombinant ovine uterine serpin ( $\mathrm{rOvUS}$ ) as determined by ATP content/well. Ovalbumin (OVA) was used as a negative control. Data represent least-squares means \pm SEM. Means that differ from untreated cells are indicated by symbols $(\dagger P<0.1$; **P $<$ $0.0 \mathrm{I} ; * * * \mathrm{P}<0.00 \mathrm{I})$.

\section{DNA fragmentation (apoptosis)}

The TUNEL procedure was used to test whether rOvUS decreased cell proliferation by induction of DNA fragmentation characteristic of apoptosis and other forms of cell death. Representative images of TUNEL labeled cells are shown in Figure 4 and the average percent of cells that were TUNEL positive is shown in Figure 5. Treatment of PC-3 with either rOvUS or the control protein OVA did

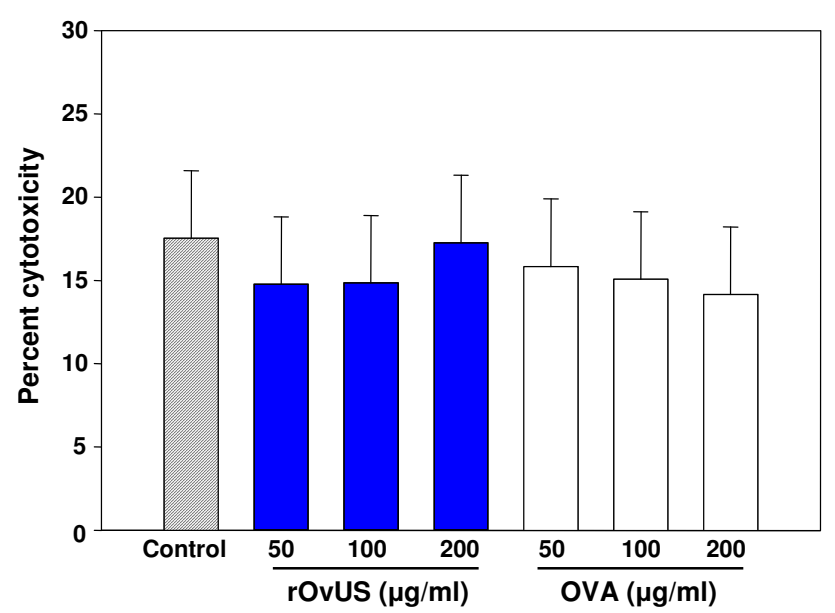

\section{Figure 3}

Lack of cytotoxic effect of recombinant ovine uterine serpin (rOvUS) on PC-3 cells was measured by the release of lactate dehydrogenase. Ovalbumin (OVA) was used as a control protein. Data represent least-squares means \pm SEM.

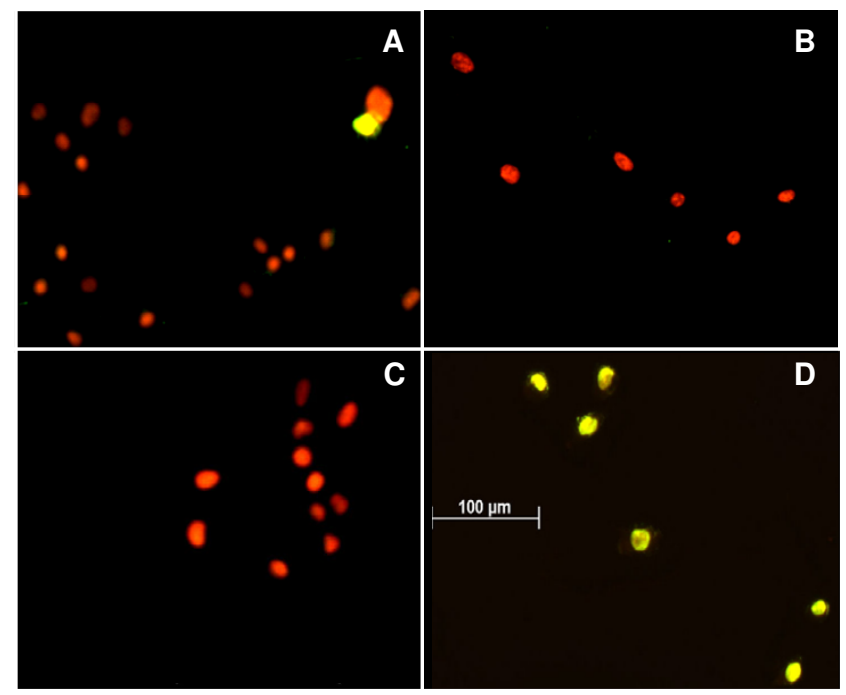

Figure 4

Representative photomicrographs of PC-3 cells labeled using the TUNEL procedure after $48 \mathrm{~h}$ of culture with either 100 (A) or $200 \mu \mathrm{g} / \mathrm{ml}$ (B) of rOvUS or $200 \mu \mathrm{g} / \mathrm{ml}$ of the control protein ovalbumin $(C)$. Cells in panel $D$ were treated with DNAse as a positive control.

not increase the percent of cells that were TUNEL positive at either 24 or $48 \mathrm{~h}$ after treatment; the percentage of cells that were TUNEL positive was low for all groups $(<5.7 \%)$. The fact that rOvUS did not induce apoptosis makes the action of this serpin distinct from that of two other serpins that inhibit cell proliferation. Both maspin [6] and PEDF [7] are proapoptotic serpins.

\section{Interleukin-8 secretion}

Interleukin- 8 accumulation in the medium was measured because of the autocrine effect of this chemokine on prostate cell proliferation [26]. In addition, at least one class of molecule that inhibits PC-3 cell proliferation, soy isoflavones, also reduces IL-8 secretion [27]. As shown in Figure 6, there was, however, no effect of rOvUS on accumulation of IL-8 into conditioned cultured medium. Thus, rOvUS does not block PC-3 cell proliferation through inhibition of IL-8 secretion.

\section{Cell cycle dynamics}

Dynamics through the different phases of the cell cycle were affected by the treatment of PC-3 cells with rOvUS. Representative DNA histograms after treatment with vehicle or $200 \mu \mathrm{g} / \mathrm{ml}$ rOvUS are shown in Figures 7A and 7B while least-squares means \pm SEM for for results at 12 and $24 \mathrm{~h}$ after treatment are shown in Figures 7C and 7D, respectively. At $12 \mathrm{~h}$ after addition of treatments, rOvUS decreased $(P<0.1$ and $P<0.05$ for 100 and $200 \mu \mathrm{g} / \mathrm{ml}$ of rOvUS respectively) the percent of cells in $S$ phase and 


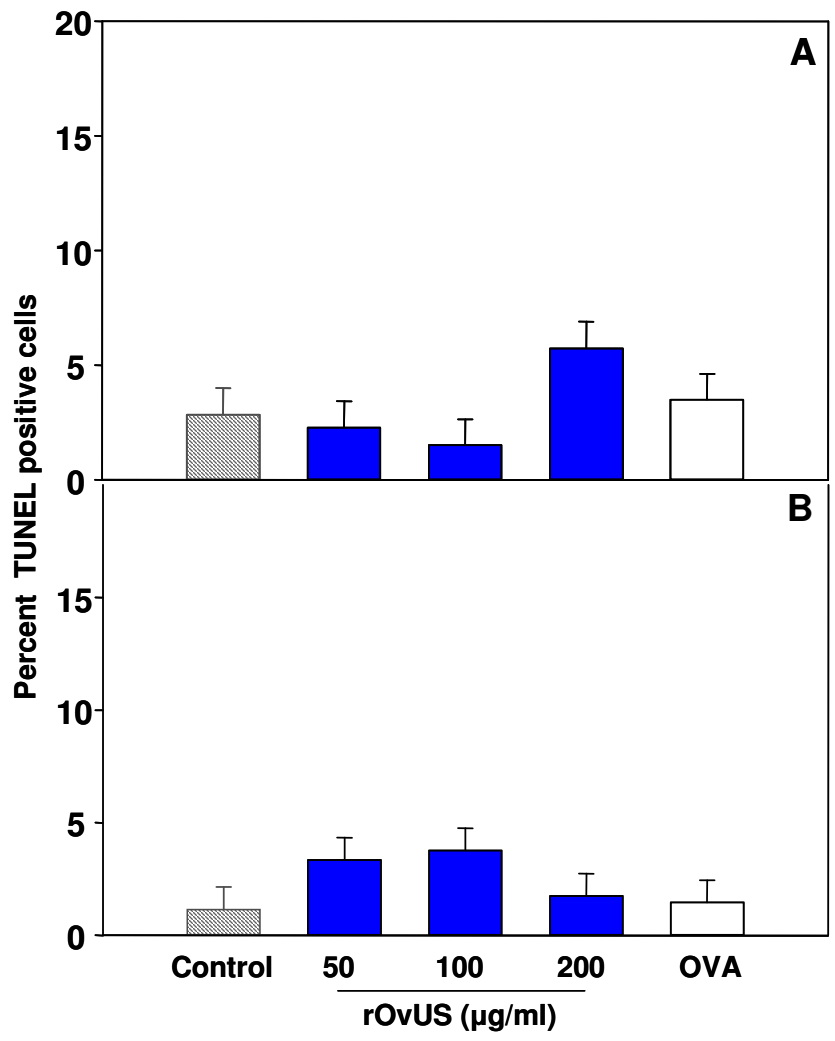

Figure 5

Effect of recombinant ovine uterine serpin (rOvUS) on DNA fragmentation (apoptosis) of PC-3 cells. Results show the percent of TUNEL positive cells at 24 (A) and 48 (B) $h$ after addition of the treatments. Data represent least-squares means \pm SEM. Ovalbumin (OVA, $200 \mu \mathrm{g} / \mathrm{ml}$ ) was used as control protein.

increased $(P<0.01)$ the percent of cells in the $G_{2} / M$ phase (Figure 6C). There was no effect of rOvUS on the percent of cells in $G_{0} / G_{1}$. At 24 h after addition of treatment, 200 $\mu \mathrm{g} / \mathrm{ml}$ rOvUS increased the percent of cells in $G_{0} / G_{1}(P<$ $0.001)$, decreased the percent of cells in $S$ phase $(P<$ 0.01 ), and did not affect the percent of cells in $G_{2} / M$ phase (Figure 6D).

Control of the cell cycle dynamics by rOvUS was also evaluated in a second cell type - the peripheral blood lymphocyte. Representative DNA histograms for PHA-treated lymphocytes are shown for control cells and cells treated with $200 \mu \mathrm{g} / \mathrm{ml}$ rOvUS in Figures $8 \mathrm{~A}$ and $8 \mathrm{~B}$, respectively while least-squares means \pm SEM are shown in Figures $8 \mathrm{C}$ and 8D. At both 72 (Figure 8C) and $96 \mathrm{~h}$ (Figure 8D) after addition of PHA, rOvUS increased $(\mathrm{P}<0.001)$ the proportion of lymphocytes in the $G_{0} / G_{1}$ phase and decreased ( $P$ $<0.05)$ the proportion of cells in the S phase. In contrast, there was no effect of the control protein (OVA) on the distribution of cells in the cell cycle.

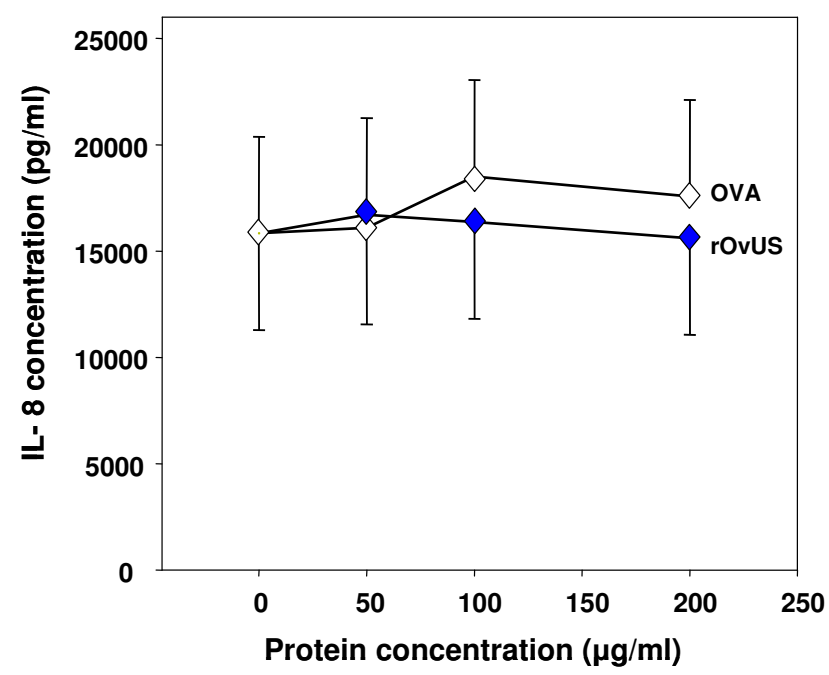

Figure 6

Effect of recombinant ovine uterine serpin (rOvUS) on interleukin (IL) -8 concentration in cell culture supernatants of PC-3 cells. Ovalbumin (OVA) was used as control serpin. Data represent least-squares means \pm SEM.

These results indicate that OvUS block cell proliferation through cell cycle arrest in both PC-3 cells and lymphocytes. The differences in specific stages at which the cell cycle was blocked between PC-3 cells and lymphocytes is likely to be caused by differences in activation and regulation pathways for these two cell types. Unlike PC-3 cells, lymphocytes are arrested at $\mathrm{G}_{0}$ until proliferation is induced by addition of PHA. Inhibition at points in the cell cycle other than $G_{0} / G_{1}$ are less likely to be seen since few cells progress to later stages of the cell cycle. In addition, it is possible that genetic mutations in PC-3 cells compromise some potential regulatory mechanisms. In particular, unlike lymphocytes, PC-3 cells lack functional p53 [28] which causes cell cycle arrest at $\mathrm{G}_{1} / \mathrm{S}$ by inducing p21 cip1 that inhibits cyclin dependent kinases $[29,30]$.

The mechanism by which OvUS inhibits cell cycle dynamics is not understood. One serpin has been identified which can affect cell cycle regulatory proteins. This serpin, myeloid and erythroid nuclear termination stage-specific protein (MENT), is a nuclear protein that inhibits cell proliferation through interactions with a nuclear protein with papain-like cysteine proteinase activity [31]. Inhibition of the proteinase prevents degradation of the cell cycle protein $\mathrm{Rb}$ although antiproliferative effects may depend more on other actions of MENT to mediate euchromatin condensation in an Rb-independent manner [31]. In any case, OvUS, is apparently without proteinase inhibitory activity and is an extracellular protein that is unlikely to achieve a nuclear localization. The antipepsin activity of 

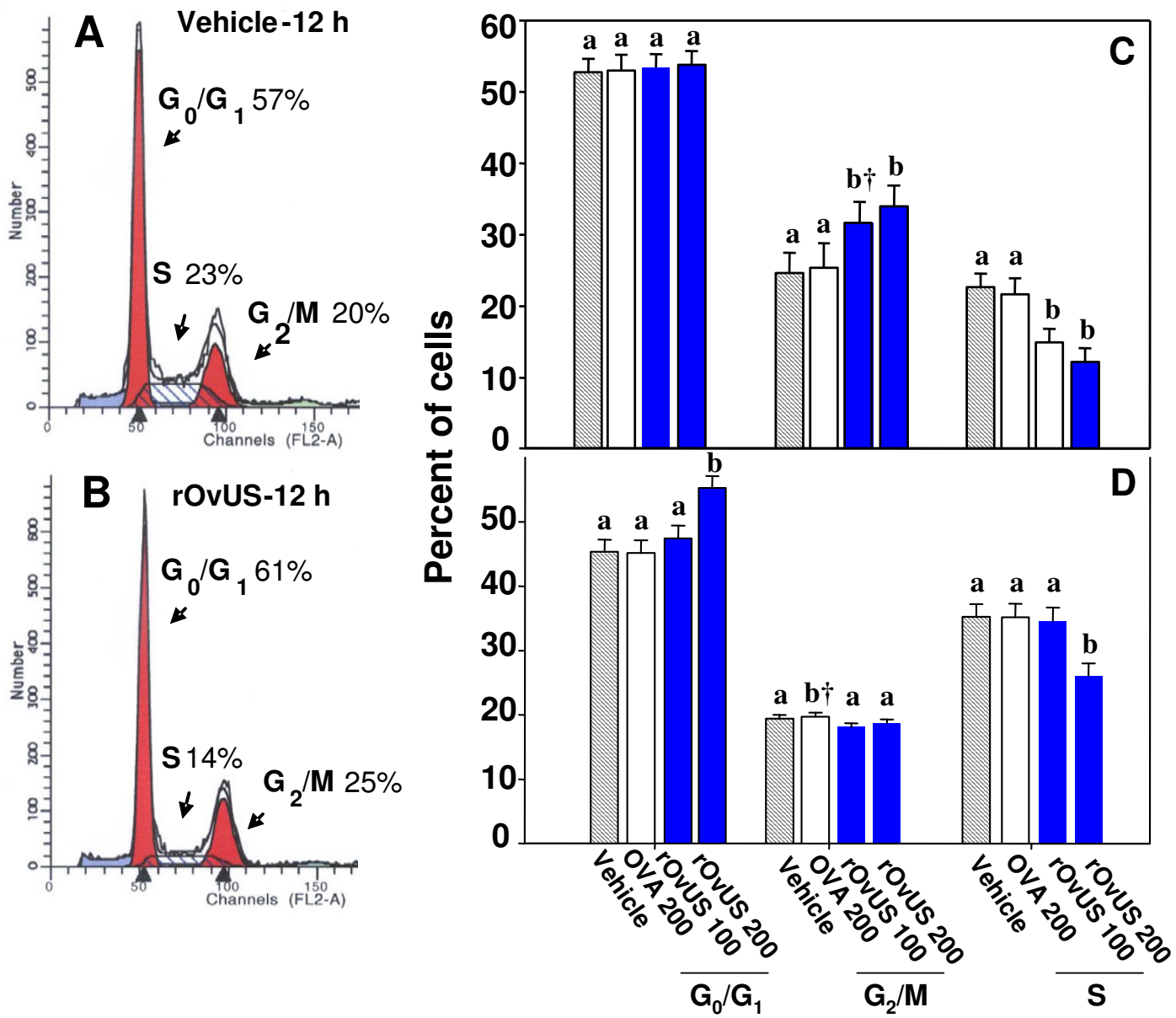

Figure 7

Cell cycle dynamics of PC-3 cells as affected by recombinant ovine uterine serpin (rOvUS). Controls included vehicle (control) and ovalbumin (OVA). Representative DNA histograms for analysis at $12 \mathrm{~h}$ after treatment with vehicle or $200 \mu \mathrm{g} / \mathrm{ml} \mathrm{rOvUS}$ are shown in panels $A$ and $B$, respectively. The least-squares means for results of three separate assays are shown in panels $C$ and D for analysis at $12 \mathrm{~h}(\mathrm{C})$ and $24 \mathrm{~h}(\mathrm{D})$ after treatment. Bars with different superscripts differ $(\dagger P<0$. 10 , others at $P<$ 0.05 or less).

uterine serpin is probably not biologically significant. OvUS is a very weak inhibitor of pepsin C (a 35 and 8 fold molar excess of OvUS was required to inhibit pepsin A and $\mathrm{C}$ [12]) $\mathrm{C}$ and the binding of OvUS to pepsin is electrostatic [15]. Moreover, pepsin shows an acidic pH optimum and is unlikely to be involved in cell proliferation under the conditions utilized.

A major point in the cell cycle regulated by OvUS is transition from $G_{0} / G_{1}$ to $S$ phase: rOvUS decreased the proportion of cells in $S$ phase in all experiments and increased the proportion of cells in $G_{0} / G_{1}$ at $24 \mathrm{~h}$ after treatment for PC-3 cells and at both times examined for lymphocytes. Ovine uterine serpin can bind to cell membranes [32] and, perhaps, OvUS inhibits proliferation by activation of signal transduction systems that inhibit tran- sition from $G_{0} / G_{1}$ to $S$ phase or prevents pro-proliferative molecules in culture medium from binding their receptors. Experiments with Rp-8-Cl-cAMPS, a selective inhibitor of cAMP-dependent type-I protein kinase A, indicated that effects of OvUS on proliferation of PHA-stimulated lymphocytes are not dependent on this kinase [24]. Studies to determine activation of other anti-proliferative signal transduction systems by OvUS are warranted.

\section{Conclusion}

The present study indicates that the mechanism by which OvUS inhibits proliferation of PC-3 cells and lymphocytes involves cell cycle arrest and not, at least for PC3 cells, apoptosis, cytotoxicity or inhibition of IL-8 secretion. 

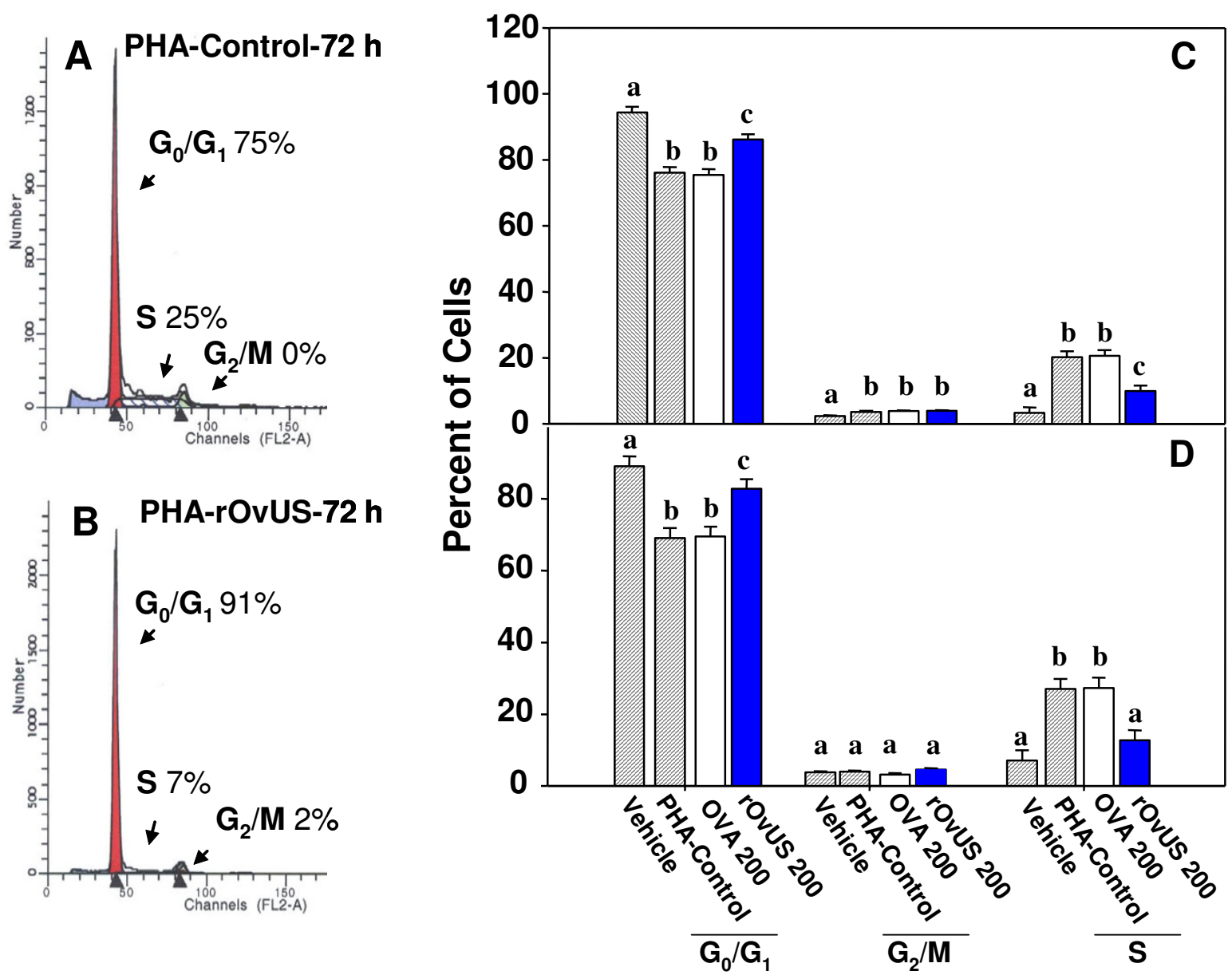

Figure 8

Cell cycle dynamics of lymphocytes as affected by recombinant ovine uterine serpin (rOvUS). Controls included vehicle (control), phytohemagglutinin (PHA) and ovalbumin (OVA). Representative DNA histograms for analysis at $72 \mathrm{~h}$ after treatment with PHA or $200 \mu \mathrm{g} / \mathrm{ml}$ rOvUS are shown in panels $A$ and B, respectively. The least-squares means for results of four separate assays are shown in panels $C$ and $D$ for analysis at $72 \mathrm{~h}(C)$ and $96 \mathrm{~h}(\mathrm{D})$ after treatment. Bars with different superscripts differ $(\mathrm{P}<0.05$ or less).

\section{Methods}

\section{Materials}

The human prostate cancer (PC-3) cell line was purchased from ATCC (Rockville, MD), the FreeStyle ${ }^{\mathrm{TM}} 293$ expression medium, Dulbecco's Modified Eagle Medium Nutrient Mixture F-12 (DMEM-F12) and 0.25\% Trypsin-EDTA were obtained from Gibco-Invitrogen (Carlsbad, CA), the RQ1 RNase-free DNase and the CellTiter-Glo ${ }^{\circledast}$ Luminescent Cell Viability Assay kit were obtained from Promega, (Madison, WI), the DHL ${ }^{\mathrm{TM}}$ Cell Cytotoxicity Assay kit was from Anaspec (San Jose, CA) and the ELISA MAX ${ }^{\mathrm{TM}}$ Set Deluxe kit for human IL-8 was obtained from BioLegend (San Diego, CA). The in situ cell death detection kit [terminal deoxynucleotidyl transferase-mediated dUTP nick end labeling (TUNEL)] was purchased from Roche (Indianapolis, IN), the DNase-free RNase A was obtained from Qia- gen (Valencia, CA), Precast Tris-HCl gradient Ready gels ${ }^{\circledast}$ were from BioRad (Richmond, $\mathrm{CA}$ ) and $\left.{ }^{3} \mathrm{H}\right]$ thymidine (6.7 Ci/mmol) was from ICN (Irvine, CA). The Prolong Antifade $^{\varpi}$ kit was purchased from Molecular Probes (Eugene, OR), Geneticin was from Research products international (Mount Prospect, IL), Centricon filter devices were from Millipore Corporation (Bedford, TX), niquel Sepharose chromatography medium (high performance) was from Amersham Biosciences (Piscataway, $\mathrm{NJ})$, fetal bovine and horse serum from Atlanta Biologicals (Norcross, GA). Other reagents were obtained from either Fisher (Pittsburg, PA) or Sigma-Aldrich (St. Louis, $\mathrm{MO})$. 


\section{Purification of rOvUS}

The His-tagged rOvUS was purified from conditioned medium of FreeStyle ${ }^{\mathrm{TM}}$ human embryonic kidney (HEK)293F cells (Gibco-Invitrogen, Carlsbad, CA) transfected with a plasmid construct containing the gene for OvUS. Details of the cell line are provided elsewhere [25]. Cells were cultured continuously in selective medium [FreeStyle $^{\mathrm{TM}} 293$ expression medium containing $700 \mu \mathrm{g} / \mathrm{ml}$ of Geneticin ${ }^{\circledast}$ at $37^{\circ} \mathrm{C}$ in a humidified $8 \%(\mathrm{v} / \mathrm{v}) \mathrm{CO}_{2}$ incubator according to the manufacturer's recommendations. Conditioned medium containing rOvUS was diluted 1:1 $(\mathrm{v} / \mathrm{v})$ in binding buffer $[20 \mathrm{mM}$ sodium phosphate buffer, $35 \mathrm{mM}$ imidazole, $0.3 \mathrm{M} \mathrm{NaCl}, \mathrm{pH}$ 8.0] and loaded into a nickel Sepharose column that was pre-equilibrated with binding buffer. The His-tagged rOvUS was eluted with 20 $\mathrm{mM}$ phosphate buffer, $500 \mathrm{mM}$ imidazole, $0.3 \mathrm{M} \mathrm{NaCl}$, $\mathrm{pH}$ 8.0, concentrated and buffer-exchanged into Dulbecco's phosphate buffered saline (DPBS) using Centricon plus-20 concentration devices. Purity of the rOvUS was assessed by sodium dodecyl sulfate-polyacrylamide gel electrophoresis using precast $4-15 \%$ polyacrylamide Tris-HCl gradient gels. The protein concentration was determined by Bradford assay [33] using bovine serum albumin as standard.

For each experiment, rOvUS and the control protein, OVA, were added to culture wells of PC-3 cells or lymphocytes dissolved in DPBS. The vehicle control included addition of DPBS at the same volume as for rOvUS and OVA. The actual volume of protein or vehicle added varied between experiments but was generally 14-25 $\mu$ land never more than $50 \mu \mathrm{l}$. Cultures were set up so that the volume of DPBS was the same in all wells.

\section{PC-3 cell culture}

The PC-3 cell line was cultured continuously in Dulbecco's Modified Eagle Medium Nutrient Mixture F-12 (DMEM-F12) supplemented with $10 \%(\mathrm{v} / \mathrm{v})$ heat-inactivated fetal bovine serum, $200 \mathrm{U} / \mathrm{ml}$ penicillin and $2 \mathrm{mg} /$ $\mathrm{ml}$ streptomycin at $37^{\circ} \mathrm{C}$ in a humidified $5 \%(\mathrm{v} / \mathrm{v}) \mathrm{CO}_{2}$ incubator. For the IL- 8 experiment only, the medium was modified to reduce the fetal bovine serum concentration to $4 \%(\mathrm{v} / \mathrm{v})$. For all the experiments, cells were cultured in $75 \mathrm{~cm}^{2}$ flasks until they reached $50-70 \%$ of confluence. Cells were then trypsinized, centrifuged at $110 \times \mathrm{g}$ for 5 min and resuspended in fresh complete medium. Cell viability was assessed by trypan blue exclusion and cell concentration was adjusted according to the requirements of each experiment.

\section{[ ${ }^{3} \mathrm{H}$ ] Thymidine incorporation by PC-3 cells}

PC-3 cells $(100 \mu \mathrm{l})$ were plated overnight at a final concentration of $1 \times 10^{5} \mathrm{cell} / \mathrm{ml}$ in a 96-well plate. Afterwards, various concentrations of rOvUS $(0,0.5,1,2,4,8,16,32$, 64,125 and $250 \mu \mathrm{g} / \mathrm{ml}$ ) or vehicle were added to each well in a total volume (including additional culture medium) of $200 \mu \mathrm{l}$. After $48 \mathrm{~h}$ of culture, $0.1 \mu \mathrm{Ci}\left[{ }^{3} \mathrm{H}\right]$ thymidine in $10 \mu \mathrm{l}$ of culture medium were added. Cells were harvested $24 \mathrm{~h}$ after $\left[{ }^{3} \mathrm{H}\right]$ thymidine addition onto fiberglass filters using a cell harvester (Brandel, Gaithersburg, $\mathrm{MD})$. Filters were counted for radioactivity using scintillation spectrometry (Beckman Coulter Inc., Fullerton, CA). Each concentration of protein was tested in triplicate and the experiment was performed in six different replicates using a different batch of rOvUS for each replicate.

\section{Cell proliferation based on ATP content}

Aliquots of $50 \mu \mathrm{l}$ of PC- 3 cells $\left(1 \times 10^{5}\right.$ cells $\left./ \mathrm{ml}\right)$ were cultured for $24 \mathrm{~h}$ in a dark wall-clear bottom 96 well plate. Then, treatments consisting of vehicle (DPBS) or three different concentrations $(50,100$ and $200 \mu \mathrm{g} / \mathrm{ml})$ of rOvUS or a control protein (OVA) and culture medium added to bring the final volume to $100 \mu \mathrm{l}$. Additional control wells without cells were prepared to determine background. At $48 \mathrm{~h}$ after addition of treatments, ATP content per well was determined using the CellTiter-Glo ${ }^{\circledR}$ Luminescent Cell Viability Assay kit according to the manufacturer's instructions. Briefly, $100 \mu \mathrm{l}$ of the CellTiter-Glo ${ }^{\circledR}$ reagent were added to each well, contents of the plate were mixed on a shaker for $2 \mathrm{~min}$ and then incubated at room temperature for $10 \mathrm{~min}$. Chemiluminescence was quantified using a multi-detection microplate reader (FLX-800, BioTek, Winooski, VT). All treatments were performed in triplicates and the assay was performed on three different occasions using a different batch of rOvUS for each replicate.

\section{Cytotoxicity assay}

The assay was based on the release of lactate dehydrogenase into culture medium following loss of cell membrane integrity accompanying cell death [34]. Procedures for cell culture and treatments were similar to those described for the ATP assay. At $48 \mathrm{~h}$ after addition of the treatments, release of lactate dehydrogenase into the medium was determined using the $\mathrm{DHL}^{\mathrm{TM}}$ Cell Cytotoxicity Assay kit following the vendor's instructions. Briefly, the plate was equilibrated at room temperature for $20 \mathrm{~min}$ before adding $10 \mu \mathrm{l}$ of lysis solution or DPBS. To facilitate cell lysing, the plate was placed on a shaker for $2 \mathrm{~min}$. A total of $50 \mu$ lactate dehydrogenase assay solution was then added to each well. After $10 \mathrm{~min}$ at room temperature, the reaction was stopped using $20 \mu \mathrm{l}$ of the stop solution and the fluorescence intensity was measured using a multi-detection microplate reader (FLX-800) with excitation and emission wavelengths of 530-560 $\mathrm{nm}$ and 590 $\mathrm{nm}$, respectively. Percent cytotoxicity was calculated by dividing $100 \times$ fluorescence from the unlysed cells by fluorescence of the lysed cells. For each assay, each treatment was performed in six wells. The assay was replicated five different times using a different batch of rOvUS for each replicate. 


\section{TUNEL labeling}

An aliquot of $100 \mu \mathrm{l}$ of PC-3 cells were cultured overnight in chamber slides at a final concentration of $1 \times 10^{4}$ cells/ $\mathrm{ml}$. Then, treatments consisting of vehicle (DPBS), 50, 100 or $200 \mu \mathrm{g} / \mathrm{ml}$ rOvUS, or $200 \mu \mathrm{g} / \mathrm{ml}$ OVA were added and additional culture medium added to produce a final volume of $300 \mu \mathrm{l}$. After 24 and $48 \mathrm{~h}$ in culture with treatments, cells were washed with PBS/PVP [100 mM sodium phosphate $\mathrm{pH} 7.4,0.9 \%(\mathrm{w} / \mathrm{v}) \mathrm{NaCl}, 1 \mathrm{mg} / \mathrm{ml}$ polyvinyl pyrrolidone] and fixed with $4 \%(\mathrm{w} / \mathrm{v})$ paraformaldehyde for $1 \mathrm{~h}$ at room temperature. Cells then were washed in PBS/PVP and stored at $4{ }^{\circ} \mathrm{C}$ for the TUNEL (terminal deoxynucleotidyl transferase and fluorescein isothiocyanateconjugated dUTP nick end labeling) procedure.

For TUNEL labeling, fixed cells were incubated for $1 \mathrm{~h}$ at room temperature with permeabilization solution [PBS, $\mathrm{pH} 7.4,0.1$ (v/v) Triton X-100, 0.1\% (w/v) sodium citrate). After washing with PBS/PVP, slides were incubated with $50 \mu$ l of TUNEL reaction mixture containing terminal deoxynucleotidyl transferase and fluorescein isothiocyanate-conjugated dUTP, for 1 hour at $37^{\circ} \mathrm{C}$. Positive controls were preincubated with RQ1 RNase-free DNase (50 $\mathrm{U} / \mathrm{ml}$ ) and negative controls were incubated without transferase. Slides were washed with PBS/PVP, incubated for $1 \mathrm{~h}$ with $50 \mu \mathrm{g} / \mathrm{ml}$ of RNase A and then for $30 \mathrm{~min}$ with propidium iodide $(2.5 \mu \mathrm{g} / \mathrm{ml})$ at room temperature. Slides were washed with PBS/PVP and Prolong Antifade ${ }^{\circledR}$ was used to mount coverslips. Samples were observed using a Zeiss Axioplan 2 fluorescence microscope with dual filter (Carl Zeiss, Inc., Göttingen, Germany). Percent of cells with DNA fragmentation was determined by counting the total number of nuclei and total number of TUNEL-labeled nuclei at 10 different sites on the slide. The experiment was performed using three different batches of rOvUS.

\section{Secretion of IL-8}

PC-3 cells $(100 \mu \mathrm{l})$ were cultured in wells of a 96-well plate overnight at a final concentration of $1 \times 10^{5} \mathrm{cells} / \mathrm{ml}$. Treatments were then added including vehicle (DPBS, similar volume as for rOvUS and OVA treatments), and three different concentrations of rOvUS and OVA (50, 100 and $200 \mu \mathrm{g} / \mathrm{ml}$ ). The volume of each well was brought to $200 \mu \mathrm{l}$ with culture medium. At $48 \mathrm{~h}$ after addition of treatments, cell culture supernatants were collected, centrifuged and stored at $-20^{\circ} \mathrm{C}$ until ELISA for IL8 . Treatments were performed in triplicate for each assay; the experiment was repeated on three different occasions using three different batches of the recombinant protein. For the measurement of IL-8, the ELISA MAX ${ }^{\mathrm{TM}}$ Set Deluxe kit for human IL-8 was used according to the manufacturer's instructions using $100 \mu \mathrm{l}$ of conditioned medium.

\section{Cell cycle analysis}

PC-3 cells $(100 \mu \mathrm{l})$ were cultured in 4 well plates at a final concentration of $4 \times 10^{5}$ cells $/ \mathrm{ml}$. After $24 \mathrm{~h}$, treatments consisting of vehicle, 100 and $200 \mu \mathrm{g} / \mathrm{ml} \mathrm{rOvUS}$, and 200 $\mu \mathrm{g} / \mathrm{ml}$ OVA were added with additional culture medium for a total volume of $400 \mu \mathrm{l}$. At 12 and $24 \mathrm{~h}$ after addition of treatments, cells were collected by trypsinization and washed with DPBS. Cells were fixed overnight in 70\% (v/ v) ethanol at $4{ }^{\circ} \mathrm{C}$, washed with DPBS and resuspended with $500 \mu \mathrm{l}$ of staining solution [DPBS pH 7.4, 0.1\% (v/ v) Triton X-100, $0.05 \mathrm{mg} / \mathrm{ml}$ DNase-free RNase A, $50 \mu \mathrm{g} /$ $\mathrm{ml}$ propidium iodide]. Cells were then analyzed by flow cytometry using a FACSort flow cytometer (Becton Dickinson, Franklin Lakes, NJ) and the red fluorescence of single events was recorded at wavelengths of $488 \mathrm{~nm}$ (excitation) and $600 \mathrm{~nm}$ (emission). Data were gated using pulse width and pulse area to exclude doublets, and the percent of cells present in each phase of the cell cycle was calculated using ModFITLT V3.1 software (Verity Software, Topsham, ME). The experiment was performed on three occasions with five different batches of rOvUS.

For the sheep lymphocyte experiment, mononuclear cells were purified by density gradient centrifugation from the buffy coat of heparinized peripheral blood collected by jugular venipuncture from non pregnant Rambouillet ewes [35]. After removing red blood cells by incubation with red cell lysis buffer $(0.01 \mathrm{M}$ Tris- $\mathrm{HCl} \mathrm{pH} 7.5$ containing $8.3 \mathrm{~g} / \mathrm{L}$ of ammonium chloride), cell viability was assessed by trypan blue exclusion, and concentration adjusted to $4 \times 10^{6}$ cells $/ \mathrm{ml}$. Cells were then suspended in a culture medium consisting of Tissue Culture Medium199 containing 5\% (v/v) horse serum, $200 \mathrm{U} / \mathrm{ml}$ penicillin, $0.2 \mathrm{mg} / \mathrm{ml}$ streptomycin, $2 \mathrm{mM}$ glutamine and $10^{-5} \mathrm{M}$ $\beta$-mercaptoethanol and aliquots of $100 \mu \mathrm{l}$ cells cultured in 4 well plates in the presence or absence of $4 \mu \mathrm{g} / \mathrm{ml}$ PHA and with treatments of DPBS vehicle, $200 \mu \mathrm{g} / \mathrm{ml} \mathrm{rOvUS}$, and $200 \mu \mathrm{g} / \mathrm{ml}$ OVA. Total culture volume was $400 \mu \mathrm{l}$. After 72 and $96 \mathrm{~h}$ in culture at $37^{\circ} \mathrm{C}$ in a humidified $5 \%$ $(\mathrm{v} / \mathrm{v}) \mathrm{CO}_{2}$ incubator, lymphocytes were collected and washed with DPBS. Thereafter, lymphocytes were fixed and treated as described above. The experiment was performed separately for lymphocytes from four different sheep. Three different batches of rOvUS were tested for each sheep.

\section{Statistical analysis}

Data were analyzed by least-squares means analysis of variance using the General Linear Models Procedures of SAS (SAS System for Windows, Version 9.0; SAS Institute, Cary, NC, USA). Error terms were determined based on calculation of expected mean squares with replicate considered random and other main effects considered fixed. For the cytotoxicity and IL-8 data, orthogonal polynomial contrasts were used to determine the linear and quadratic 
effects of rOvUS and OVA. In other analysis, the pdiff mean separation test of SAS was used to distinguish the difference of various levels of a treatment.

\section{Abbreviations}

IL-8: Interleukin-8; Maspin: Mammary serine proteinase inhibitor; MENT: Myeloid and erythroid nuclear termination stage-specific protein; OVA: Ovalbumin; PC-3: Prostate cancer-3; PEDF: Pigment epithelium derived factor; PHA: Phytohemagglutinin; TUNEL: Terminal deoxynucleotidyl transferase (TdT) and fluorescein isothiocyanateconjugated dUTP nick end labeling; US: Uterine serpin.

\section{Authors' contributions}

MBP carried out all of the studies described, participated in experimental design and drafted the manuscript. PJH conceived of the study, participated in its design and coordination, and helped to draft the manuscript. Both authors read and approved the final manuscript.

\section{Acknowledgements}

The authors want to thank Neal Bensen and Steve McClellan from the Flow Cytometry Core Laboratory, Facility of the Interdisciplinary Center of Biotechnology Research, University of Florida and to Luciano Bonilla for help with the sheep. Thanks are also extended to the following University of Florida people for providing access to laboratory equipment: Dr. Owen Rae and Shelley Lanhart from the Department of Large Animal Clinical Sciences, Dr. Lori Warren and Jan Kivilpeto from the Department of Animal Sciences, and Dr. Pushpa Kalra from the Dept. of Physiology and Functional Genomics.

\section{References}

I. Irving JA, Pike RN, Lesk AM, Whisstock JC: Phylogeny of the serpin superfamily: Implications of patterns of amino acid conservation for structure and function. Genome Res 2000, 10:1845-1864

2. Van Gent D, Sharp P, Morgan K, Kalsheker N: Serpins: structure, function and molecular evolution. Int J Biochem Cell Biol 2003, 35: $1536-1547$

3. Law RHP, Zhang Q, McGowan S, Buckle AM, Silverman GA, Wong W, Rosado CJ, Langendorf CG, Pike RN, Bird PI, Whisstock JC: An overview of the serpin superfamily. Genome Biol 2006, 7:216.

4. Pemberton PA, Stein PE, Pepys MB, Potter JM, Carrell RW: Hormone binding globulins undergo serpin conformational change in inflammation. Nature 1988, 336:257-258.

5. Sauk Jj, Nikitakis N, Siavash H: Hsp47 a novel collagen binding serpin chaperone, autoantigen and therapeutic target. Front Biosci 2005, 10:107-118.

6. Sheng S: A role of novel serpin maspin in tumor progression: the divergence revealed through efforts to converge. J Cell Physiol 2006, 209:631-635.

7. Fernandez-Garcia NI, Volpert OV, Jimenez B: Pigment epitheliumderived factor as a multifunctional antitumor factor. J Mol Med 2007, 85:15-22.

8. Moffatt J, Bazer FW, Hansen PJ, Chun PW, Roberts RM: Purification, secretion and immunocytochemical localization of the uterine milk proteins, major progesterone-induced proteins in uterine secretions of the sheep. Biol Reprod 1987, 36:419-430.

9. Ing NH, Roberts RM: The major progesterone-induced proteins secreted into the sheep uterus are members of the serpin superfamily of protease inhibitors. J Biol Chem 1989, 264:3372-3379.

10. Malathy PV, Imakawa K, Simmen RC, Roberts RM: Molecular cloning of the uteroferrin-associated protein, a major progesterone-induced serpin secreted by the porcine uterus, and expression of its mRNA during pregnancy. Mol Endocrinol 1990 , 4:428-440.

II. Leslie MV, Hansen PJ, Newton GR: Uterine secretions of the cow contain proteins that are immunochemically related to the major progesterone-induced proteins of the sheep uterus. Domest Anim Endocrinol 1990, 7:517-526.

12. Mathialagan N, Hansen TR: Pepsin-inhibitory activity of uterine serpins. Proc Natl Acad Sci 1996, 93: I3653-13658.

13. Tekin S, Padua MB, Newton GR, Hansen PJ: Identification and cloning of caprine uterine serpin. Mol Reprod Dev 2005, 70:262-270.

14. Peltier MR, Raley LC, Liberles DA, Benner SA, Hansen PJ: Evolutionary history of the uterine serpins. J Exp Zool 2000, 288: $165-174$.

15. Peltier MR, Grant TR, Hansen PJ: Distinct physical and structural properties of the ovine uterine serpin. Biochim Biophys Acta 2000, 1479:37-5I.

16. Liu WJ, Hansen PJ: Progesterone-induced secretion of dipeptidyl peptidase-IV (cell differentiation antigen 26 ) by the uterine endometrium of the ewe and cow that costimulates lymphocyte proliferation. Endocrinology 1995, 136:779-787.

17. Hansen PJ: Regulation of uterine immune function by progesterone-lessons from the sheep. J Reprod Immunol 1998, 40:63-79.

18. Segerson EC, Moffatt RJ, Bazer FW, Roberts MR: Suppression of phytohemagglutinin-stimulated lymphocyte blastogenesis by ovine uterine milk protein. Biol Reprod 1984, 30: I I75-I I 86.

19. Hansen PJ, Segerson EC, Bazer FW: Characterization of immunosuppressive substances in the basic protein fraction of uterine secretions of pregnant ewes. Biol Reprod 1987, 36:393-403.

20. Skopets B, Hansen PJ: Identification of the predominant proteins in uterine fluids of unilaterally pregnant ewes that inhibit lymphocyte proliferation. Biol Reprod 1993, 49:997-1007.

21. Skopets B, Liu WJ, Hansen PJ: Effects of endometrial serpin-like proteins on immune responses in sheep. Am J Reprod Immunol 1995, 33:86-93.

22. Peltier MR, Liu WJ, Hansen PJ: Regulation of lymphocyte proliferation by uterine serpin: interleukin- 2 mRNA production, CD25 expression and responsiveness to interleukin-2. Exp Biol Med I 999, 223:75-8I.

23. Liu WJ, Hansen PJ: Effect of the progesterone-induced serpinlike proteins of the sheep endometrium on natural-killer cell activity in sheep and mice. Biol Reprod 1993, 49:1008-1014.

24. Tekin S, Padua MB, Brad AM, Hansen PJ: Antiproliferative actions of ovine uterine serpin. Am J Reprod Immunol 2005, 53:136-I43.

25. Tekin S, Padua MB, Brad AM, Rhodes ML, Hansen PJ: Expression and properties of recombinant ovine uterine serpin. Exp Biol Med 2006, 231: 1313-1322.

26. Araki S, Omori Y, Lyn D, Singh RK, Meinbach DM, Sandman $Y$, Lokeshwar VB, Lokeshwar BL: Interleukin-8 is a molecular determinant on androgen independence and progression in prostate cancer cells. Cancer Res 2007, 67:6854-6862.

27. Handayani R, Rice L, Cui Y, Medrano TA, Samedi VG, Baker HV, Szabo NJ, Shiverick KT: Soy isoflavones alter expression of genes associated with cancer progression, including interleukin-8, in androgen-independent PC-3 human prostate cancer cells. I Nutr 2006, 136:75-82

28. Isaacs WB, Carter BS, Erwing CM: Wild-type p53 supresses growth of human prostate cancer cells containing mutant p53 alleles. Cancer Res 199I, 5 I:4716-4720.

29. Harper JW, Adami GR, Wei N, Keyomarsi K, Elledge SJ: The p2I Cdk-interacting protein Cipl is a potent inhibitor of GI cyclin dependent kinases. Cell 1993, 75:805-816.

30. Duliæ V, Kaufmann WK, Wilson SJ, Tlsty TD, Lees E, Harper JW, Elledge SJ, Reed SI: p53-dependent inhibition of cyclin-dependent kinase activities in human fibroblasts during radiationinduced GI arrest. Cell 1994, 76:1013-1023.

31. Irving JA, Shushanov SS, Pike RN, Popova EY, Bromme D, Coetzer THT, Bottomley SP, Boulynko IA, Grigoryev SA, Whisstock JC: Inhibitory activity of a heterochromatin-associated serpin (MENT) against papain-like cysteine proteinases affects chromatin structure and can regulate cell proliferation. J Biol Chem 2002, 277:13192-13201.

32. Liu WJ, Peltier MR, Hansen PJ: Binding of ovine uterine serpin to lymphocytes. Am J Reprod Immunol 1999, 4I:428-432. 
33. Bradford MM: A rapid and sensitive method for the quantitation of microgram quantities of protein utilizing the principle of protein-dye binding. Anal Biochem 1976, 78:248-254.

34. Decker T, Lohmann-Matthes ML: A quick and simple method for the quantitation of lactate dehydrogenase release in measurements of cellular cytotoxicity and tumor necrosis factor (TNF) activity. J Immunol Methods 1988, I I 5:61-69.

35. Tekin S, Hansen PJ: Natural-killer like cells in the sheep: Functional characterization and regulation by pregnancy-associated proteins. Exp Biol Med (Maywood) 2002, 227:803-8II.

Publish with Biomed Central and every scientist can read your work free of charge

"BioMed Central will be the most significant development for disseminating the results of biomedical research in our lifetime. "

Sir Paul Nurse, Cancer Research UK

Your research papers will be:

- available free of charge to the entire biomedical community

- peer reviewed and published immediately upon acceptance

- cited in PubMed and archived on PubMed Central

- yours - you keep the copyright

Submit your manuscript here:

http://www.biomedcentral.com/info/publishing_adv.asp
BiolMedcentral 